\title{
Sperm Morphophysiology in Different Sections of the Rooster Reproductive Tract
}

\author{
Morfofisiología Espermática en Diferentes Secciones del Tracto Reproductivo del Gallo
}

\author{
Jorge A. González-Santos'; Alejandro Ávalos-Rodríguez²; José A. Martínez-García²; \\ Ana M. Rosales-Torres² \& José A. Herrera-Barragán²
}

GONZÁlez-SANTOS, J. A.; ÁVAloS-RODRÍGUEZ, A.; MARTÍNEZ-GARCÍA, J. A.; ROSALES-TORRES, A. M. \& HERRERA-BARRAGÁN, J. A. Sperm morphophysiology in different sections of the rooster reproductive tract. Int J. Morphol., 37(3):861-866, 2019.

SUMMARY: It is important to know the morphological changes that occur in the spermatozoa of rooster during their passage through the reproductive tract, which help to understand what they acquire their fertilization capacity. The morphophysiological changes related to the capacitation and acrosomal reaction processes in the different segments of the rooster reproductive system were analyzed. Samples were obtained from various regions of the rooster reproductive tract and dorso-ventral massage to obtain ejaculates, 25 roosters were used Rhode Island Red with proven fertility, assessments were performed with chlortetracycline and Lectin WGA-FITC to determine the morphophysiological parameters. Sperm motility increases $(\mathrm{p}<0.05)$ during the passage of spermatozoa from the testis until they are ejaculated. The parameters of viability and morphology also show differences $(p<0.05)$ in the different segments of the tract. Sperm morphometry shows a spermatic contraction $(\mathrm{p}<0.05)$ in the cranial and medial segments of the vas deferens. The acrosomal reaction capacity evaluated with chlortetracycline (CTC) or Wheat germ agglutinin (WGA), was evident increasing the parameters ( $\mathrm{p}<0.05)$ with the use of the perivitelline layer in the spermatozoa of the reproductive tract and of the ejaculate. Spermatozoa of the reproductive tract of the rooster demonstrate acrosomal reaction capacity without requiring a previous sperm capacitation condition. On the other hand, they do not show parameters of incapacity, which implies that they cannot be stored in any segment of the reproductive tract.

KEY WORDS: Acrosome; Carbohydrates; Membrane; Vas deferens.

\section{INTRODUCTION}

A specialized region or structure similar to epididymis in mammals that participates on sperm cell nutrition and maturation processes is lacking on the rooster reproductive tract. So it would be relevant to specify which structure of the vas deferens are subjected to a maturation process before ejaculation. Either sperm cell maturation occurs in the female reproductive system or, it is not needed, as it has been reported that a sperm sample obtained from the testicle may fertilize oocytes in vivo (Howarth, 1983). Sperm storage tubules (SST) have been found on the hen reproductive tract and they are located at the utero-vaginal junction in the oviduct (Holt, 2011; Sasanami et al., 2012). Rooster sperm cells are able to survive between two and fifteen weeks in the SST (Bakst, 2011).

A consensus has not been reached regarding the site where capacitation and acrosome reaction occur, i.e. whether in females or males (Lemoine et al., 2009 \& Ahammad et al., 2011a). Biochemical changes and modifications to cell membrane fluidity occur during capacitation of mammalian sperm, in addition to intercellular $\mathrm{pH}$ shifts, increased permeability to $\mathrm{Ca}^{2+}$ ions, modification of protein phosphorylation patterns and lipid composition (Albarracín et al., 2004). Sperm cell capacitation is a pre-requisite for the acrosome reaction in mammalian sperm in order to attain their fertilizing ability (Jones et al., 2007). However, it is not clear if a capacitation process similar to that in mammals is needed before the rooster sperm cells attain their fertilizing ability (Ahammad et al., 2011b). Sperm cell capacitation was evaluated in Meleagris gallopavo by using chlortetracycline (CTC). Morphophysiological changes were observed because an increase of intracytoplasmic $\mathrm{Ca}^{2+}$ (Herrera et al., 2017b). Additionally, the N-Acetylglucosamine and sialic acid exhibited by glycoproteins on the sperm cell membrane are involved in gamete recognition in order to achieve fertilization (Cardona Maya et al., 2005; Hernández Cruz et al., 2005). Lectin Wheat germ agglutinin (WGA) conjugated with

\footnotetext{
${ }^{1}$ Doctorado en Ciencias Agropecuarias, Universidad Autónoma Metropolitana-Xochimilco, México.

${ }^{2}$ Departamento de Producción Agrícola y Animal; Universidad Autónoma Metropolitana-Xochimilco, México.
} 
isitiosionate of fluoresceine (WGA-FITC) has been used to identify these carbohydrates in vitro. Intracellular $\mathrm{Ca}^{2+}$ distribution and the presence of membrane carbohydrates correlate with both capacitation and acrosome reaction processes and these events are assessed in order to evaluate the sperm's fertilizing ability. Therefore, the morphophysiological changes that sperm cells undergo during both capacitation and acrosome reaction processes were analyzed in this study that includes different regions of the reproductive system and the ejaculate.

\section{MATERIAL AND METHOD}

Ethical considerations. In accordance with the NOM-062ZOO-1999 (Norma Oficial Mexicana, 2011) standard regarding the care and use of laboratory animals, 25 Rhode Island Red roosters were used.

Sperm collection. Ejaculates were obtained by aspiration after performing a dorsoventral massage, once per day (NOM-062-ZOO-1999). Roosters were euthanized according to NOM-033-SAG/ZOO-2014 (Norma Oficial Mexicana, 2015), in order to obtain spermatozoa from the testicle and the different vas deferens regions (cranial, medial, and caudal). Subsequently, they were collected in Eppendorf tubes containing $500 \mu \mathrm{L}$ of Lake solution, $(0.09$ $\mathrm{M}$ sodium glutamate, $0.04 \mathrm{M}$ fructose, $0.003 \mathrm{M}$ magnesium acetate, and $0.05 \mathrm{M}$ potassium acetate, $\mathrm{pH}$ of 7.2 , and a 330 mOsm osmolarity). Sperms were collected from the tissues by swim up (Herrera et al., 2005), and they were kept at 5 ${ }^{\circ} \mathrm{C}$ in Lake solution until further evaluation (Herrera et al., 2017b).

Semen basic evaluation. Sperm concentration was determined by optic microscopy with a Neubauer chamber. Motility was analyzed at 400x. Sperm viability and morphology were evaluated by eosin-nigrosin vital staining (1\% eosin and $5 \%$ nigrosin) using microscope (Olympus BX51) immersion oil at 100X. Two hundred cells were evaluated by preparation (Santiago-Moreno et al., 2011 \& Herrera et al., 2017a).

Evaluation of $\mathrm{Ca}^{2+}$ distribution. $500 \mu \mathrm{L}$-aliquots of Lake solution containing $5 \times 106$ sperm cells were incubated. To evidence $\mathrm{Ca}^{2+}$ presence and its distribution, $10 \mu \mathrm{L}$ of a clortetracicline (CTC) solution $(0.009 \mathrm{M})$ was previously incubated during ten minutes at $37{ }^{\circ} \mathrm{C}$ in thermal stage protected from the light (Ochoa et al., 2014 \& Herrera et al., 2017a).

Assessment of N- acetylglucosamine distribution. A 10 $\mu \mathrm{L}$-aliquot of a lectin WGA -FITC solution was incubated as a $1: 50$ dilution at $37^{\circ} \mathrm{C}$ during thirty minutes protected from the light. It was later centrifuged $(2,897 \mathrm{G} \times 1 \mathrm{~min})$, the supernatant was discarded and the cell pellet was suspended with $5 \mu \mathrm{L}$ ethanol at $2{ }^{\circ} \mathrm{C}$ until further evaluation. After these aliquots were prepared, they were placed on glass slides to be visualized under a fluorescence microscope at 100X, using excitation and emission wavelengths of 488 $\mathrm{nm}$ and $560 \mathrm{~nm}$, respectively (Herrera et al., 2005). For data processing, one hundred sperm cells were counted and the images were evaluated using the Image Pro Plus software, version 6.2.1.

The test conditions were taken into account when the sperm cell sample was obtained and evaluated in a post mortem time period less than $10 \mathrm{~min}$. These are suitable conditions for sperm cell capacitation 10 and also to evaluate their ability to undergo acrosome reaction. The latter was induced by incubating $5 \times 106$ sperm cells with $20 \mu \mathrm{L}$ of perivitelline layer (PVL) and kept for $40 \mathrm{~min}$ at $37^{\circ} \mathrm{C}$ (Ahammad et al., 2011b).

Statistical Analysis. A randomized model and a ShapiroWilk test were used to evaluate normality, whereas the Levene test was used for homoscedasticity. A variance analysis was performed to evaluate fluorescence pattern changes with CTC and PVL+CTC. When differences occurred, a Tukey test was carried out. Differences regarding the effect by region were estimated with a Kruskal-Wallis test after performing the basic evaluation and the WGA or PVL+WGA-FITC fluorescence patterns. The data was analyzed using the R Studio software (Macintosh; Intel Mac OS X 10_11_1, version 0.99.484-@ 2009-2015 R Studio, Inc.) with a $\mathrm{P}<0.05$ significance level.

\section{RESULTS}

Semen basic evaluation. Sperm cell motility is significantly different between regions, $11.3 \%$ mobility was observed in the testis region and this value increased after ejaculation $(90.0 \%)$. The live spermatozoa percentage differed among the different regions: a $91.40 \%$ value was found in sperm samples collected from testis, whereas the highest value (97.86\%) was observed on the caudal region. The highest percentage $(94.80 \%)$ of sperm cells possessing normal morphology was found in the caudal region, with significant differences $(\mathrm{P}<0.05)$ among regions. Subsequently, taking into account these indicators (motility, live spermatozoa and normal morphology), the sperm cell's ability to undergo biochemical changes was assessed during its passage through the vas deferens until their ejaculation (Table I). 
GONZÁLEZ-SANTOS, J. A.; ÁVALOS-RODRÍGUEZ, A.; MARTíNEZ-GARCíA, J. A.; ROSALES-TORRES, A. M. \& HERRERA-BARRAGÁN, J. A. Sperm morphophysiology in different sections of the rooster reproductive tract. Int J. Morphol., 37(3):861-866, 2019.

Table I. Evaluation seminal basic in different sections of the vas deferens and ejaculate.

\begin{tabular}{|c|c|c|c|c|c|c|}
\hline \multirow{2}{*}{ Sperm cell Indicator } & \multirow{2}{*}{ Testicle } & \multicolumn{3}{|c|}{ Vas deferens } & \multirow{2}{*}{ Ejaculate } & \multirow{2}{*}{ SEM } \\
\hline & & Cranial & Medial & Caudal & & \\
\hline Motility (\%) & $11.33 \mathrm{e}$ & $56.33 \mathrm{~d}$ & $73.00_{c}$ & $78.00 \mathrm{~b}$ & $90.00 \mathrm{a}$ & 1.08 \\
\hline Viability (\%) & $91.40 \mathrm{c}$ & $93.93 \mathrm{~b}^{\mathrm{c}}$ & $95.66 \mathrm{ba}$ & $97.86 \mathrm{a}$ & $96.46 \mathrm{~b}^{\mathrm{a}}$ & 0.79 \\
\hline Morphology (\%) & $89.26^{\mathrm{b}}$ & $84.60 \mathrm{c}$ & $90.86 \mathrm{ba}$ & $94.80 \mathrm{a}$ & $91.40 \mathrm{~b}^{\mathrm{a}}$ & 1.28 \\
\hline
\end{tabular}

Different letters on different region rows represent significant differences $(\mathrm{P}<0.05)$. Values are expressed as mean and SEM $(n=25)$.

Table II. Length of the sperm from vas deferens and ejaculate of the rooster.

\begin{tabular}{lclllll}
\hline \multirow{2}{*}{ Sperm Indicator $(\mathrm{n}=15)$} & \multirow{2}{*}{ Testicle } & \multicolumn{3}{c}{ Vas deferens } & \multirow{2}{*}{ Ejac ulate } & \multirow{2}{*}{ SEM } \\
\cline { 3 - 5 } & & Craneal & Medial & Caudal & & \\
\hline Head length $(\mu \mathrm{m})$ & $17.56 \mathrm{a}$ & $16.49 \mathrm{a}$ & $15.84^{\mathrm{a}}$ & $16.34^{\mathrm{a}}$ & $16.36 \mathrm{a}$ & 0.47 \\
Midpiece $(\mu \mathrm{m})$ & $4.73 \mathrm{a}$ & $4.57^{\mathrm{b}}$ & $4.01 \mathrm{~b}^{\mathrm{c}}$ & $3.92^{\mathrm{c}}$ & $4.17^{\mathrm{bac}}$ & 0.15 \\
Tail length $(\mu \mathrm{m})$ & $69.19 \mathrm{~b}^{\mathrm{a}}$ & $55.21 \mathrm{~b}$ & $67.74^{\mathrm{b}}$ & $70.68^{\mathrm{ba}}$ & $85.00 \mathrm{a}$ & 4.08 \\
Total length $(\mu \mathrm{m})$ & $91.49 \mathrm{~b}^{\mathrm{a}}$ & $76.29 \mathrm{~b}$ & $87.60^{\mathrm{b}}$ & $90.95^{\mathrm{ba}}$ & $105.54^{\mathrm{a}}$ & 3.96 \\
\hline
\end{tabular}

Different letters on different region rows represent significant differences $(\mathrm{P}<0.05)$. Values are expressed as mean and SEM.

As indicated in Table II, the sperm morphometric indicators showed significant differences $(\mathrm{P}<0.05)$ in all regions. A total length of $105.54 \mathrm{~mm}$ was observed in ejaculated spermatozoa. Increases in head, neck and tail length were also observed as sperm passed through the vas deferens until their ejaculation.

Three $\mathrm{Ca}^{2+}$ distribution patterns were observed: $\mathrm{A}$, $\mathrm{B}$ and $\mathrm{C}$. The former (intact sperm cells) was characterized by fluorescence in the head, middle part and its flagellum. The B pattern (sperm cells that underwent capacitation) shows fluorescence in the acrosome and at the-equatorial zone and the middle section. The $\mathrm{C}$ pattern (acrosome reaction): Shows low fluorescence in the middle section and the flagellum. The pattern proportion observed on the rooster

Table III. Parameters sperm of capacitation an acrosome reaction in vitro in the presence of PVL as measured with CTC.

\begin{tabular}{llllll}
\hline & & & & \multicolumn{2}{c}{ Sperm cells (\%) } \\
\multicolumn{1}{l}{ Zone } & Treatment & Intact & Capacitated & Reaction \\
& \multirow{4}{*}{ Testicle } & Control & $62.57 \mathrm{a}$ & 24.14 & $14.57 \mathrm{a}$ \\
& $(\mathrm{n}=25)$ & PVL & $19.57 \mathrm{~b}$ & 30.57 & $45.00 \mathrm{~b}$ \\
& & SEM & 5.39 & 3.10 & 4.36 \\
& Craneal & Control & $54.71 \mathrm{a}$ & 28.43 & $19.00 \mathrm{a}$ \\
& $(\mathrm{n}=25)$ & PVL & $22.28 \mathrm{~b}$ & 33.57 & $43.57 \mathrm{~b}$ \\
Vas & SEM & 3.71 & 3.60 & 4.60 \\
deferens & Medial & Control & $59.43 \mathrm{a}$ & 26.14 & $18.71 \mathrm{a}$ \\
& $(\mathrm{n}=25)$ & PVL & $21.57 \mathrm{~b}$ & 25.29 & $52.29 \mathrm{~b}$ \\
& & SEM & 3.68 & 2.70 & 3.23 \\
& Caudal & Control & $45.43 \mathrm{a}$ & 31.57 & $28.00 \mathrm{a}$ \\
& $(\mathrm{n}=25)$ & PVL & $16.14 \mathrm{~b}$ & 27.00 & $57.29 \mathrm{~b}$ \\
& & SEM & 5.46 & 2.22 & 3.28 \\
& & Control & $66.71 \mathrm{a}$ & $18.14 \mathrm{a}$ & $16.14 \mathrm{a}$ \\
& Ejaculate & PVL & $12.571^{\mathrm{b}}$ & $26.86 \mathrm{~b}$ & $60.57 \mathrm{~b}$ \\
& $(\mathrm{n}=25)$ & SEM & 2.58 & 2.72 & 3.20 \\
\hline
\end{tabular}

Letters distinct on different treatment represent significant differences $(\mathrm{P}<0.05)$. Values are expressed as mean and standard error mean (SEM). Perivitelline layer (PVL). Clortetracicline (CTC). reproductive tract was modified after performing a coincubation of PVL.

Based on the previous classification, Table III shows the percentage of intact sperm cells that underwent capacitation along with acrosomal reaction in fresh samples and after incubation in presence of PVL. A higher percentage of intact sperm cells was observed after their ejaculation when compared to a $66.71 \%$. Value in other regions of the reproductive tract. Regarding the percentage of sperm cells undergoing capacitation, a higher percentage $(31.57 \%)$ was found at the caudal region whereas this value decreased to $18.14 \%$ after ejaculation. Thus, the caudal region may function as reservoir and, if the sperm cells therein are not ejaculated, they undergo anatomical and biochemical modifications. At the caudal region, the observed percentage values of sperm cells undergoing acrosomal reaction were $28.00 \%$ and $14.57 \%$. It can be hypothesized that, from the moment sperm cells are produced in testis they undergo important morphophysiological changes when they pass through vas deferens until their subsequent ejaculation. The latter assuming that some specialized cells reside within these ducts that induce such anatomic and physiologic changes in sperm cells. Table III shows a comparison between fresh samples and those incubated with PVL in order to induce an acrosomal reaction. In these conditions, significant differences $(\mathrm{P}<0.05)$ were observed regarding intact sperm cells in contrast to those undergoing capacitation at the 
testicular, cranial, medial, caudal and ejaculated regions. Only the percentage of sperm cells undergoing capacitation did not show significant differences in any region. An increase of sperm cells undergoing acrosome reaction was also observed after incubating with PVL when compared to fresh samples. This finding corroborates the patterns previously observed after both treatments.

Three fluorescence patterns were observed after the WGA-FITC test was performed. Pattern A: uniformly fluorescent sperm cells, implicating an intact membrane. Pattern B, sperm cells exhibiting fluorescence at the acrosome and the middle sections, thus they were classified as undergoing capacitation. Pattern C: sperm cells displaying fluorescence on the head that was greater in intensity at the acrosomal zone, thus they were considered as undergoing acrosomal reaction. Table IV shows the percentage of intact sperm cells in fresh treatment and in those incubated with PVL. Significant differences $(\mathrm{P}<0.05)$ were observed when the testicular, cranial, medial and caudal regions were compared. No differences were found on the ejaculate.

Regarding the percentage of sperm cells undergoing capacitation, no significant difference was found $(\mathrm{P}<0.05)$ in any of the regions either as fresh or in the presence of PVL. Finally, significant differences were observed when both conditions were compared regarding the percentage of sperm cells exhibiting acrosomal, specifically in the testicular, caudal and medial regions. Thus, the caudal region and those that were ejaculated did not display differences between both conditions. Similarly, the data on Table IV suggest that as sperm cells traverse the vas deferens a decrease of intact spermatozoa occurs whereas those undergoing acrosomal reaction increase. This indicates that sperm cells mature within specific regions located at the vas deferens in which they undergo physiological changes regarding their membrane structure as well as morphological changes.

Table IV. Parameters sperm of capacitation an acrosome reaction in vitro in the presence of PVL as measured with WGA-FITC.

\begin{tabular}{|c|c|c|c|c|c|}
\hline \multirow{2}{*}{ Zone } & & \multirow[b]{2}{*}{ Treatment } & \multicolumn{3}{|c|}{ Sperm cells } \\
\hline & & & Intact ( \%) & Capacitated (\%) & Reaction (\%) \\
\hline \multirow{15}{*}{$\begin{array}{l}\text { Vas } \\
\text { deferens }\end{array}$} & \multirow{3}{*}{$\begin{array}{l}\text { Testicle } \\
(n=15)\end{array}$} & Control & $44.71 \mathrm{a}$ & 23.86 & $23.57^{\mathrm{a}}$ \\
\hline & & PVL & $14.86 \mathrm{~b}$ & 18.29 & $55.71 \mathrm{~b}$ \\
\hline & & SEM & 3.52 & 3.25 & 6.99 \\
\hline & \multirow{3}{*}{$\begin{array}{l}\text { Craneal } \\
(\mathrm{n}=15)\end{array}$} & Control & $49.49 \mathrm{a}$ & 29.00 & $13.86^{\mathrm{a}}$ \\
\hline & & PVL & $13.71 \mathrm{~b}$ & 29.43 & $55.29 \mathrm{~b}$ \\
\hline & & EEM & 3.46 & 4.99 & 3.77 \\
\hline & \multirow{3}{*}{$\begin{array}{l}\text { Medial } \\
(n=15)\end{array}$} & Control & $41.00 \mathrm{a}$ & 27.71 & $10.14^{\mathrm{a}}$ \\
\hline & & PVL & $16.57 \mathrm{~b}$ & 35.29 & $56.14 \mathrm{~b}$ \\
\hline & & SEM & 5.941 & 5.88 & 4.11 \\
\hline & \multirow{3}{*}{$\begin{array}{l}\text { Caudal } \\
(n=15)\end{array}$} & Control & $13.29 \mathrm{a}$ & 25.71 & 47.71 \\
\hline & & PVL & $20.86 \mathrm{~b}$ & 23.71 & 57.29 \\
\hline & & SEM & 2.15 & 5.29 & 6.00 \\
\hline & \multirow{3}{*}{$\begin{array}{l}\text { Ejaculate } \\
(\mathrm{n}=25)\end{array}$} & Control & 18.14 & 26.14 & 57.14 \\
\hline & & PVL & 16.29 & 31.57 & 52.00 \\
\hline & & SEM & 2.29 & 5.30 & 5.01 \\
\hline
\end{tabular}

Letters distinct on different treatment represent significant differences $(\mathrm{P}<0.05)$. Values are expressed as mean and standard error mean (SEM). Perivitelline layer (PVL). Wheat Germ Agglutinin lectin (WGA).

\section{DISCUSSION}

The results obtained in this study showed an increased sperm cell motility from the moment they pass through the vas deferens until they are ejaculated. This is important as the sperm cell is enabled to fertilize the oocyte (Mocé et al., 2010). However, this increased sperm cell motility renders them energetic because of their limited mitochondrial content until the moment they attain the hyperactivation movement (Etches, 1996), a particular feature of capacitated sperm
(Ochoa et al.). This movement ceases, suggesting the existence of an inactivating process occurring on the chicken SST, as previously pointed (Sasanami et al.). An increased motility at the vas deferens has been in Coturnix japonica (Nixon et al., 2014). They observed a testicular motility value of $20 \%$, whereas this value was $80 \%$ at the vas deferens caudal section. The values we obtained for rooster in this study was $11.33 \%$ in testis and $78 \%$ at the caudal section. 
This finding supports the use of $\mathrm{G}$ gallus as an experimental model to collect motile sperm cells from a different bird species in order to be used for breeding or preservation purposes. In this work we also assessed the percentage of live sperm cells in testis $(91.40 \%)$ and after ejaculation $(96.46 \%)$. These percentage values o were similar to those by others studies (Herrera et al., 2005 \& Santiago-Moreno et al.). In vitro fertilization (IVF) requires the highest amount of live spermatozoa, although low concentrations are used to perform oocyte fertilization (Mizushima et al., 2014). The parameters observed in this study regarding sperm cell morphology showed $89.2 \%$ of normal spermatozoa in testis and $91.40 \%$ in the ejaculate. These percentages agree with those obtained in other study they observed $89.8 \%$ of normal morphology in G gallus (Tabatabaei et al., 2009). The Lake medium was used for both viability and morphology assessments of normal sperm cells in this study as it preserved these variables, probably because of its composition, low osmolarity and $\mathrm{pH}$. Similar results were obtained by other authors who used this medium (Umapathy et al., 2005 \& Herrera et al., 2005).

Similarly, sperm cell morphometry was found to be relevant as maturation and anatomical changes were evidenced when they pass from the testis to the vas deferens to be finally ejaculated. An average size value of $91.49 \mathrm{~mm}$ was measured for spermatozoa in testis that subsequently changed to $105.5 \mathrm{~mm}$ after their ejaculation. This result is different from that reported by Long (2006), as they observed an 80-90 mm size in G. gallus sperm cells. Regarding the percentages of fresh capacitated sperm cells and those displaying acrosomal reaction observed after a CTC staining, we found $57.77 \%$ of intact spermatozoa along the reproductive tract until their ejaculation: $25.68 \%$ of them underwent capacitation and $19.28 \%$ displayed an acrosomal reaction. However, these values changed after they were coincubated with PVL as $18.42 \%$ of intact sperm cells was detected in all sections: $28.65 \%$ of them were capacitated and $51.74 \%$ were characterized by an acrosomal reaction. These results suggest that sperm cells located in G. gallus testis possess a fertilizing ability, as previously demonstrated (Howarth), after performing an intramagnal insemination in hens. Similarly, the hypothesis stating that bird spermatozoa do not need to access the female reproductive tract in order to undergo the processes leading to oocyte fertilization is supported by our results. 6,10 Based on this, it is confirmed that sperm cells collected from different sections of the male reproductive tract may be used by different techniques of assisted reproduction in order to preserve endangered birds or those possessing a genetic and commercial value. This, based on the fact that a high percentage of intact spermatozoa is obtained that may be able to withstand cryopreservation if required, but also on the amount of capacitated sperm cells as well as those displaying acrosomal reaction to be used for IVF or artificial insemination.

Regarding the WGA-FITC lectin staining, $\mathrm{N}$-acetylglucosamine was identified in rooster spermatozoa and the observed patterns indicate its distribution. When intact spermatozoa displayed fluorescence in its entire structure indicated that $\mathrm{N}$-acetyl-glucosamine receptors are still internalized within the plasma membrane (Cardona Maya et al.). Spermatozoa displaying fluorescence at the acrosome and in the post-equatorial zone were identified as capacitated. Cholesterol levels on the spermatozoon plasma membrane regulate the abundance of these carbohydrate receptors because when capacitation occurs a cholesterol increase is observed caused by the presence of its acceptor molecules. This promotes the suitable conditions for receptor externalization to the outer plasma membrane and finally those spermatozoa with the appropriate physiological state undergo a reaction exhibiting fluorescence only in their heads. In this location the receptors are already externalized creating a spermatozoid-oocyte recognition site and thus the fertilization process is enabled. Altogether, our results indicate that rooster spermatozoa do not need a reservoir site to perform carbohydrate incorporation in order to create a spermatozoa-oocyte recognition site. This proposal is based on the fact that spermatozoa display $\mathrm{N}$-acetyl-glucosamine receptors when they are located in testis, indicating that they already possess a fertilizing ability. This capacity increases as they traverse the male's reproductive tract. Thus, we propose that spermatozoa may be collected from different regions of reproductive tract when they are to be of use for bird breeding techniques, for commercial purposes or in a broader field of opportunity such as the preservation of endangered wild species.

\section{CONCLUSION}

Spermatozoa obtained from different regions of the reproductive tract of the rooster demonstrate in vitro an acrosome reaction capacity without requiring a precondition of sperm capacitation, which may be related to its fertilizing capacity. This may be associated with its fertilization ability in vivo. Therefore, the sperm collected from different sections of the rooster reproductive tract may be used in different techniques of assisted reproduction without requiring a previous sperm capacitation.

ACKNOWLEDGMENTS: To the Consejo Nacional de Ciencia y Tecnología (CONACyT) México, for scholarships 417462 to JAGS. 
GONZÁLEZ-SANTOS, J. A.; ÁVALOS-RODRÍGUEZ, A.; MARTÍNEZ-GARCÍA, J. A.; ROSALES-TORRES, A. M. \& HERRERA-BARRAGÁN, J. A. Morfofisiología espermática en diferentes secciones del tracto reproductivo del gallo. Int. J. Morphol., 37(3):861-866, 2019.

RESUMEN: Es importante conocer los cambios morfológicos que se producen en los espermatozoides del gallo durante su paso por el tracto reproductivo y que ayudan a comprender como adquieren su capacidad de fertilización. Se analizaron cambios morfofisiológicos relacionados con los procesos de capacitación y reacción acrosomal de los espermatozoides presentes en los diferentes segmentos del tracto reproductor del gallo. Se obtuvieron espermatozoides de diferentes regiones del tracto reproductor del gallo y de espermatozoides de eyaculado. Se usaron 25 gallos Rhode Island Red con fertilidad probada. Se realizaron evaluaciones básicas, con clortetraciclina (CTC) y lectina Wheat germ agglutinin conjugada con isotiosionato de fluoresceína (WGA-FITC) para determinar los parámetros morfofisiológicos. La motilidad del esperma aumenta $(\mathrm{P}<0,05)$ durante el paso de los espermatozoides desde el testículo hasta que son eyaculados. Los parámetros de viabilidad y morfología también muestran diferencias $(\mathrm{P}<0,05)$ en los diferentes segmentos del tracto. La morfometría mostró una contracción de los espermatozoides $(\mathrm{P}<0,05)$ en los segmentos craneal y medial del conducto deferente. La capacidad de reacción acrosomal evaluada con clortetraciclina CTC o WGAFITC, fue evidente al aumentar los parámetros $(\mathrm{P}<0,05)$ con el uso de membrana perivitelina en los espermatozoides del tracto reproductivo y del eyaculado. los espermatozoides del tracto reproductivo del gallo demuestran capacidad de reacción acrosomal sin requerir una condición previa de capacitación espermática. Por otro lado, no muestran parámetros de descapacitación espermática lo que implica que no pueden almacenar en ningún segmento del tracto reproductivo.

PALABRAS CLAVE: Acrosoma; Carbohidratos; Membrana; Conducto deferente.

\section{REFERENCES}

Ahammad, M. U.; Nishino, C.; Tatemoto, H.; Okura, N.; Kawamoto, Y.; Okamoto, S. \& Nakada, T. Maturational changes in the survivability and fertility of fowl sperm during their passage through the male reproductive tract.Anim. Reprod. Sci., 128(1-4):129-36, 2011a.

Ahammad, M. U.; Nishino, C.; Tatemoto, H.; Okura, N.; Kawamoto, Y.; Okamoto, S. \& Nakada, T. Maturational changes in motility, acrosomal proteolytic activity, and penetrability of the inner perivitelline layer of fowl sperm, during their passage through the male genital tract. Theriogenology, 76(6):1100-9, $2011 b$.

Albarracín, J. L.; Mogas, T.; Palomo, M. J.; Peña, A.; Rigau, T. \& Rodríguez-Gil, J. E. In vitro capacitation and acrosome reaction of dog spermatozoa can be feasibly attained in a defined medium without glucose. Reprod. Domestic. Anim., 39(3):129-35, 2004.

Bakst, M. R. Role of the oviduct in maintaining sustained fertility in hens. J. Anim. Sci., 89(5):1323-9, 2011.

Cardona Maya, M. D.; Berdugo Gutiérrez, J.A.; de los Ríos, J. \& Cadavid Jaramillo, A. P. Functional evaluation of sperm in Colombian fertile men. Arch. Esp. Urol., 60(7):827-31, 2005

Etches, J. R. Reproduction in Poultry. Wallingford, CAB International, 1996. pp.234-61.

Hernández Cruz, P.; Pérez Campos, E.; Martínez Martínez, L. \& Martínez, G. Las lectinas vegetales como modelo de estudio de las interacciones proteína-carbohidrato. Rev. Educ. Bioquim., 24(1):21-7, 2005.

Herrera, J. A.; Calderon, G.; Cruz, C.; Avila, M. A.; Quintero, G. E. \& Fierro, R. C.
Changes in the membrane carbohydrates from sperm cryopreserved with dimethylsulfoxide or polyvinylpyrrolidone of red-tailed hawk (Buteo jamaicencis). Cryo Letters, 38(4):257-62, 2017 a.

Herrera, J. A.; Calderón, G.; Guzmán, A.; Vargas, A. K.; Ávalos, A. \& Rosales, A. M. Evaluation of two diluents for the storage of fresh and cryopreserved semen of Harris hawk (Parabuteo unicinctus). Austral J. Vet. Sci., 49(1):39-43, $2017 \mathrm{~b}$.

Herrera, J. A.; Quintana, J. A.; López, M. A.; Betancourt, M. \& Fierro, R. Individual cryopreservation with dimethyl sulfoxide and polyvinylpyrrolidone of ejaculates and pooled semen of three avian species. Arch. Androl., 51(5):353$60,2005 \mathrm{c}$

Holt, W. V. Mechanisms of sperm storage in the female reproductive tract: an interspecies comparison. Reprod. Domest. Anim., 46 Suppl. 2:68-74, 2011.

Howarth, B. Jr. Fertilizing ability of cock spermatozoa from the testis epididymis and vas deferens following intramagnal insemination. Biol. Reprod., 28(3):58690, 1983.

Jones, R. C.; Dacheux, J. L.; Nixon, B. \& Ecroyd, H. W. Role of the epididymis in sperm competition. Asian J. Androl., 9(4):493-9, 2007.

Lemoine, M.; Dupont, J.; Guillory, V.; Tesseraud, S. \& Blesbois, E. Potential involvement of several signaling pathways in initiation of the chicken acrosome reaction. Reprod. Biol., 81(4):657-65, 2009.

Long, J. A. Avian semen cryopreservation: what are the biological challenges? Poult. Sci., 85(2):232-6, 2006.

Mizushima, S.; Hiyama, G.; Shiba, K.; Inaba, K.; Dohra, H.; Ono, T.; Shimada, K. \& Sasanami, T. The birth of quail chicks after intracytoplasmic sperm injection. Development, 141(19):3799-806, 2014.

Mocé, E.; Purdy, P. H. \& Graham, J. K. Treating ram sperm with cholesterolloaded cyclodextrins improves cryosurvival.Anim. Reprod. Sci., 118(2-4):23647, 2010.

Nixon, B.; Ewen, K. A.; Krivanek, K. M.; Clulow, J.; Kidd, G.; Ecroyd, H. \& Jones, R. C. Post-testicular sperm maturation and identification of an epididymal protein in the Japanese quail (Coturnix coturnix japonica). Reproduction, 147(3):265-77, 2014.

Norma Oficial Mexicana. NOM-062-ZOO-1999. Technical specifications for the production, care and use of laboratory animals. Ciudad de México, Diario Oficial de la Federación, 2001.

Norma Oficial Mexicana. NORMA Oficial Mexicana NOM-033-SAG/ZOO-2014, Methods to kill domestic and wild animals. Ciudad de México, Diario Oficial de la Federación, 2015.

Ochoa, F.; Val, D.; Juárez, A.; Toscano, I.; Olivo, I. \& Conejo, J. Identificación del estado funcional de la membrana plasmática del espermatozoide de guajolote nativo durante el proceso de criopreservación. Actas Iberoam. Conserv. Anim., 4:123-5, 2014.

Santiago-Moreno, J.; Castaño, C.; Toledano-Díaz, A.; Coloma, M. A.; LópezSebastián, A.; Prieto, M. T. \& Campo, J. L. Semen cryopreservation for the creation of a Spanish poultry breeds cryobank: optimization of freezing rate and equilibration time. Poult. Sci., 90(9):2047-53, 2011

Sasanami, T.; Matsuzaki, M.; Mizushima, S. \& Hiyama, G. Sperm storage in the female reproductive tract in birds. J. Reprod. Dev., 59(4):334-8, 2012.

Tabatabaei, S.; Batavani, R. A. \& Talebi, A. R. Comparison of semen quality in indigenous and ross broiler breeder roosters. J. Anim. Vet. Adv., 8(1):90-3, 2009.

Umapathy, G.; Sontakke, S.; Reddy, A.; Ahmed, S. \& Shivaji, S. Semen characteristics of the captive Indian white-backed vulture (Gyps bengalensis). Biol. Reprod., 73(5):1039-45, 2005.

Corresponding author:

José Antonio Herrera Barragán:

Calzada del Hueso 1100

Col. Villa Quietud

Delegación Coyoacán

C.P. 04960

MÉXICO

Received: 20-10-2018

Accepted: 04-02-2019
Email: herreraaves@gmail.com jherrerab@correo.xoc.uam.mx 